\title{
Inflation, budget culs, and faculty needs
}

Ed. note: Although economists inform us that the recession was officially over in March 1991, the library newsletters arriving at the C\&RL News office are filled with stories about budget cuts, serials cancellations, employment freezes, and otber effects of the tight economy. We thought that the following "Dean's Column" prepared by David Walch for the California Polytechnic State University Library Update did an excellent job of explaining these cutbacks to the library's constituency and that readers might find in it some useful ideas. (Reprinted with permission.)

Consider the following:

- Five years ago the average cost of a book was $\$ 34.92$; today the average cost is $\$ 52.08$, an increase of $49 \%$.

- Five years ago the average cost of a journal was $\$ 128.55$; today the average cost is $\$ 233.22$, an increase of $82 \%$.

- Five years ago the library subscribed to 3,313 journals, and paid $\$ 426,000$; today it subscribes to 2,983 journals and pays nearly $\$ 700,000$, an increase in cost of $82 \%$.

- Five years ago the library purchased 14,608 books. At this writing the library has not purchased a book in over 3 months.

- Five years ago the library employed 70.5 FTE; today it has a staff of 57 FTE, a reduction of $24 \%$

When one combines these five-year inflationary trends with the fact that the library's budget for purchasing books and journals did not increase, but rather decreased, during this period of time by approximately $13 \%$, then one begins to comprehend the difficult condition the library finds itself in.

To accommodate the inflation factor and the budget cuts the library must not only trim book purchases but also cut even more journal and serial titles. While cutting subscriptions is never easy, the progress made with the electronic access does cushion the blow.

With the UNCOVER system now available to every faculty and student outside the library, via the network, the number of journals accessed electronically number over 12,000 , far more than Cal Poly's library ever held.
It is true that with electronic access the user is unable to go to the shelf, find the volume, and photocopy the article immediately, but the article can be faxed for near immediate delivery (for a fee), or ordered through interlibrary loan.

Simply put, the library must make deep cuts (approximately 30\%) of its subscriptions to journals and serials. Doing this will allow the library to retain the most heavily used journals and serials and perhaps buy a meager number of books.

During the summer the library staff have been identifying those journals that have such a high rate of use that it would be impracti$\mathrm{cal}$, and not at all cost-effective, to rely on electronic access--this will become the "Print Core Collection."

Five years ago the library subscribed to 3,313 joumals, and paid $\$ 426,000$; today it subscribes to 2,983 journals and pays nearly $\$ 700,000$, an increase. . of $82 \%$.

We have also made progress in identifying journals that may be less frequently used but accessible by electronic means and document delivery-this will become the "Electronic Core Collection."

In conjunction with this the library will do all it can to accommodate the needs of students and faculty in obtaining information that is in the electronic core collection. An improved document-delivery system is being organized to assist. It is hoped that funds will eventually be made available to subsidize the cost of faxing or downloading articles.

The library solicits the assistance of all faculty, and particularly departmental library representatives in identifying the journals and serials that will need to be trimmed from the "print core collection."

Given the inflationary trends and budget cuts experienced, electronic access is seen as the only feasible alternative.-David B. Walch, dean of libraries, California Polytechnic State University 


\section{Complete References for College and Research Libraries.}
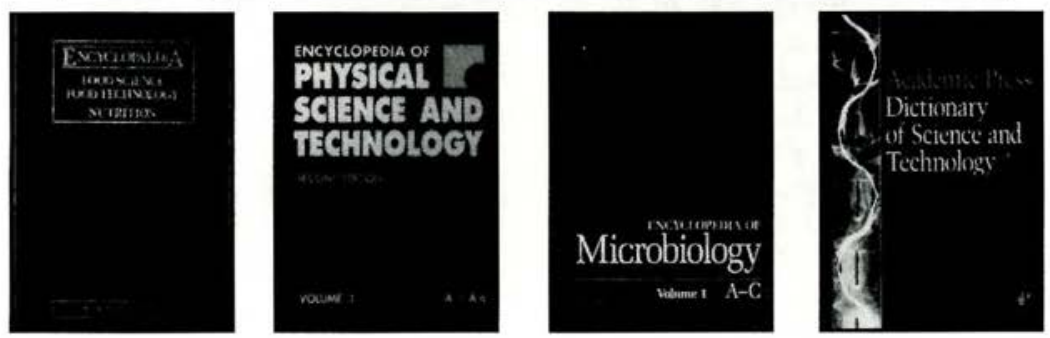

\section{Encyclopaedia} of Food Science, Food Technology and Nutrition

Edited by

Robert Macrae, Richard

Robinson, and Michéle Sadler

Key Features

- An eight-volume set including a complete subject index with more than 50,000 entries and a directory of contributors

- More than 1,500 contributors from 50 different countries

- 1030 articles written by the world's leading scientists and approved by an independent review procedure

- Tailored to suit an international audience

- Entries allow easy access for the nonspecialist reader

- Easy-to-use, meticulously organized

- Extensive cross-referencing system links related articles

- Suggestions for reading at the end of each article allow easy access to the primary literature

- 6114 pages in a large $8 \times 11^{\prime \prime}$, double-column format for clarity and accessibility

- Generously illustrated, including full color plates in each volume

Eight-Volume Set

June 1993, c. 6114 pp.

ISBN: 0-12-226850-4

Pre-publication Price: \$1795.00*

${ }^{\star}$ Expires on final day of month of publication.
Encyclopedia of Physical Science and Technology

SECOND EDITION

Edited by

Robert A. Meyers

Eighteen-Volume Set

1992, 13788 pp., $\$ 2,500.00$

ISBN: 0-12-226930-6

\section{Encyclopedia of Microbiology}

Editor-in-Chief

Joshua Lederberg

Four-Volume Set

October 1992, 2518 pp., $\$ 695.00$

ISBN: 0-12-226890-3

\section{Academic Press Dictionary of Science and Technology}

One Volume

September 1992, 2432 pp., $\$ 115.00$ ISBN: 0-12-200400-0 